УДК: 374.72(09)«18/19»

(C) Лутаєва Т.В., Жукова О.А., 2019 p.

http://orcid.org/0000-0002-5825-560X

http://orcid.org/0000-0001-9724-9598

DOI: $10.34142 / 23128046.2019 .47 .06$

T. В. Лутаєва

О. А. Жукова

\title{
РОЛЬ НАУКОВЦІВ СЛОБОЖАНЩИНИ У ПОПОВНЕННІ ІНФОРМАЦЙНОГО ПРОСТОРУ МАТЕРІАЛАМИ ПРОСВІТНИЦЬКОГО ХАРАКТЕРУ: РЕГІОНАЛЬНИЙ ІСТОРИКО-ПЕДАГОГІЧНИЙ ПІДХІД
}

Окреслюючи особисті иіннісні орієнтачії та намагаючись динамічно реагувати на запити громадського життя, сучасні фахівиі проводять дослідження просвітницької діяльності науковців як представників певних історичних періодів та регіонів. Автори статті висвітлюють роль науковиів-медиків та природодослідників Слобожанщини у поповненні інформаційного простору матеріалами просвітницького характеру наприкіниі XIX - на початку XX $\mathrm{cm}$. Цілісний аналіз цієї ролі уможливлюється розкриттям сутності поняття «інформаційний простір», обтрунтуванням значущості діяльності науковців стосовно поповнення інформаційного простору матеріалами просвітницького характеру як протягом досліджуваного періоду, так $і$ у період сьогодення. Методами дослідження було обрано: історико-ретроспективний, біографічний методи; метод історичної актуалізачії. Запропоновано розглядати інформаційний простір як домінантну складову простору культури протягом певного історичного періоду, що сприяе обгрунтуванню певної картини дійсності. Акцентовано увагу на тому, що важливими складовими інформаційного простору слід уважати спеціалізований інформачійний простір та інформачійний простір освіти. До важливих напрямів просвітницької діяльності представників наукової спільноти в інформаційному просторі віднесено просвітницьку діяльність в університетському просторі та за його межами.

Констатовано, щуо науковці-медики та природодослідники Імператорського Харківського університету, поповнюючи інформачійний простір матеріалами просвітницького характеру, уможливили діалог між поколіннями мешканців Слобожанщини й взагалі між представниками різних регіонів. Інтелектуальна діяльність науковців втрачала сугубо елітарний характер й слугувала потребам просвітительства. Визнано корисним при створенні иентрів спільного інновачійного простору у період сучасності брати до уваги досвід Харківського товариства поширення серед народу грамотності. У статті доведено, щуо матеріали науковців Слобожанщини 
стосовно значущьссті ігрової діяльності, які поширювалися в інформаційному просторі освіти протягом досліджуваного періоду, можуть бути корисними у процесі гейміфікації освіти у період сьогодення.

Ключові слова: інформачійний простір, Слобожанщина, науковиі, Харківський університет, просвітитель, просвітницька діяльність.

Lutaieva T. V., Zhukova $O$. A. The role of Slobozhanshchina scientists in completing the information space with the materials of the educational character:regional historical and pedagogical approach. Outlining personal value orientations and trying to respond dynamically to the demands of public life, modern scholars need to study the educational activities of scientists as representatives of certain historical periods and regions. The authors of the article highlight the role of scientists, physicians and natural scientists of the Slobozhanshchina in filling the information space with educational materials in the late 19th - beginning of 20th centuries. A holistic analysis of this role is made possible by revealing the essence of the concept of "information space", substantiating the importance of the activities of scientists in replenishing the information space with educational materials both during the study period and in the present period. The following research methods were selected: historical, retrospective, biographical methods; method of historical actualization. It is proposed to consider the information space as the dominant component of the space of culture during a certain historical period, which contributes to the substantiation of a certain picture of reality. Attention is drawn to the fact that specialized information space and information space of education should be considered as important components of the information space. Important areas of educational activity of representatives of the scientific community in the information space include: educational activities in the university space and beyond.

It is stated that scientists of Imperial Kharkiv University, by enriching the information space with educational materials, made possible dialogue between generations of Slobozhanshchina residents and in general between representatives of different regions. The intellectual activity of scientists lost a purely elitist character and served the needs of enlightenment. It is recognized that it is useful to take into account the experience of the Kharkiv Literacy Society when creating centers of shared innovation space in the modern times. In the article it is proved that materials of Slobozhanshchina scientists concerning the importance of game activity, which were distributed in the information space of education during the studied period, can be useful in the process of gamification of education in the present period.

Keywords: information space, Slobozhanshchina, scientists, Kharkiv University, enlightener, educational activity.

Вступ. Цінність просвітительства визнається сучасними науковцями як шлях до збагачення та поширення досягнень національної й 
загальнолюдської культури. Не випадково у «Кодексі цінностей Харківського університету», де визначаються основні ціннісні орієнтації представників згаданого закладу вищої освіти, наводяться слова В. Н. Каразіна: «Якщо щонебудь і може забезпечити непорушність ㄲï (країни) простору, то це тільки просвітительство серед народів іiї країни» (переклад авторів) (Kodeks tsinnostei Kharkivskoho natsionalnoho universytetu imeni V. N. Karazina, 2019). Визнаючи просвітительство як цінність, окреслюючи траєкторії власного розвитку та намагаючись динамічно реагувати на запити громадського життя, сучасні науковці потребують досліджень різновекторної просвітницької діяльності учених як представників певних історичних періодів та регіонів. Регіональний історико-педагогічний підхід обумовлює необхідність вивчення та аналізу життєдіяльності освітян, учених Слобожанщини, які залучалися до вирішення низки нагальних, зокрема регіональних, проблем соціального розвитку суспільства в минулому. Важливе значення у справі поширення культурних цінностей, популяризації наукових знань на Слобожанщині відводилося інформаційному простору як формі освоєння реального світу, що актуалізує тему дослідження.

Про внесок представників Слобожанщини у поповнення інформаційного простору матеріалами просвітницького характеру розмірковували сучасні дослідники (В. Садівничий, Т. Лутаєва, М. Красіков, С. Мірошніченко, Л. Віканскі та ін.). Однак, цілісного аналізу цієї ролі у зв'язку з сучасним баченням сутності поняття «інформаційний простір» здійснено не було.

Мета та завдання. Метою статті $є$ розкриття ролі науковців-медиків та природодослідників Слобожанщини у поповненні інформаційного простору матеріалами просвітницького характеру наприкінці XIX - на початку XX ст. та обгрунтування значущості започаткованих традицій у період сучасності.

Відповідно до мети дослідження поставлені такі завдання:

1. Уточнити змістове наповнення категоріального апарату дослідження, зокрема розкрити зміст поняття «інформаційний простір», звернувши увагу на осмислення його складових.

2. 3'ясувати основні напрями діяльності науковців Слобожанщини досліджуваного періоду у справі поповнення інформаційного простору матеріалами просвітницького характеру.

3. Зосередити увагу на тих підходах представників наукової спільноти Слобожанщини до просвітницької діяльності, що мають особливу наукову і практичну цінність для сучасності.

Методи дослідження. Історико-ретроспективний метод дозволив висвітлити напрями просвітницької діяльності науковців Слобожанщини у процесі поширення інформації серед широких прошарків населення. 
Використаний нами біографічний метод надав можливість виявити вплив соціуму на вибір науковцями способів просвітницької діяльності та роль окремих учених у досягненні громадськістю ідеалів Просвітництва. Метод історичної актуалізації дозволив охарактеризувати внесок окремих науковців-медиків i природодослідників Слобожанщини у справу поповнення інформаційного простору матеріалами просвітницького характеру з проекцією на сьогодення.

Результати Аналіз наукових розвідок дозволяє 3'ясувати змістове наповнення поняття «інформаційний простір», звернувши увагу на осмислення його складових. Так, поняття «інформація», за визначенням ЮНЕСКО, слід розуміти як універсальну субстанцію, що є провідником думок та знань, інструментом взаєморозуміння та співробітництва, спілкування, утвердження стереотипів мислення та поведінки (Iakovenko, 2011). Слід акцентувати увагу на тому, що поняття «простір» $\epsilon$ формоутворюючим як для поняття «інформаційний простір», так і для понять «культурний простір», «освітній простір», «простір ментальності», «університетський простір», «спільний інноваційний простір» тощо. Різним формам простору притаманно вступати у взаємодію. Не випадково більшість дослідників інтерпретують інформаційний простір як компонент простору культури (Iakovenko, 2011). Спираючись на визначення М. Яковенко, вважаємо доцільним тлумачити інформаційний простір як домінантну складову простору культури протягом певного історичного періоду, що визначає рівень, характер і спрямованість культурного розвитку та зумовлює iï провідні елементи: духовні та естетичні, наукові, освітні. Складовою інформаційного простору $є$ спеціалізований інформаційний простір. Приймаючи до уваги наукові розвідки В. Садівничого (Sadivnychyi, 2015), назване поняття слід визначати таким чином: це - середовище, в якому відбувається вироблення, зберігання, збір й поширення перевіреної, документально підтвердженої, доступної, достовірної інформації наукового змісту; інформаційна взаємодія між суб'єктами інформаційних обмінів 3 метою задоволення як власних інформаційних потреб, так і забезпечення наукових досліджень чи наукового пошуку, заходів профілактичного характеру. В інформаційному просторі прийнято також виокремлювати «інформаційний простір освіти». Вважаємо слушним зауваження М. Бака 3 приводу того, що інформаційний простір освіти слід характеризувати, приймаючи до уваги соціальні, психолого-педагогічні та культурні умови реалізації інформаційних процесів в освіті (Bak, 2014).

Привертання уваги до просвітницького характеру матеріалів науковців, що поповнювали інформаційний простір, обумовлює необхідність 
тлумачення поняття «просвітитель». У словнику української мови названа категорія визначається так: «прихильник просвітительства; пропагандист прогресивних ідей, знань, культури і т.ін.» (Bilodid, 1975).

Аналізуючи життєдіяльність представників Слобожанщини імперської доби, слід зазначити, що Слобожанщина (Слобідська Україна) - історичний регіон, який посилено розвивався з XVII ст. Ця назва походить від слова «слобода». Свого часу вона вказувала на можливість урегулювання серед населення регіону низки соціально-економічних питань без податкових зобов'язань. Відтак, у період сьогодення Слобожанщина відповідає території таких нинішніх областей: Харківської та частини Сумської, Луганської та Донецької (області України), а також частини Курської й Білгородської (області Росіі). Протягом досліджуваного періоду центром зосередження науковців Слобожанщини був Харків - зв'язуюча ланка між центральними та південними районами європейської частини Російської імперії. На початку XIX ст. на території міста був заснований Імператорський Харківський університет (Харківський університет). Відкриття університету стало важливим чинником консолідації представників наукового співтовариства саме в Харкові - центрі Слобідської України. Поняття «наукове співтовариство» («наукова спільнота») розглядаємо як соціокультурну групу науковців (учених), які працюють в одній науковій галузі або досліджують загальну проблему, і об’єднані системою певних комунікацій. Відтак до кола науковців Слобожанщини відносимо тих учених, чия професійна підготовка до наукової діяльності та діяльність на ниві вищої освіти й науки була протягом певного часу пов'язана з регіоном.

Наприкінці XIX - на початку XX ст. різнобічна просвітницька діяльність науковців-медиків та природодослідників Харківського університету знаходила відбиток у періодичних виданнях, що друкувалися науковими товариствами Харківського університету. Так, зі сторінок періодичного видання «Товариства наукової медицини i гігієни» при Імператорському Харківському університеті дізнаємося про педагогічну спрямованість досліджень доктора медицини I. Атласова (Iavlenie periodichnosti v razvitii chelovecheskogo organizma, 1904). У публікації (1901р.) були схарактеризовані новітні для того часу погляди щодо виховання й навчання молодого покоління.

На сторінках видань Товариства фізико-хімічних наук Харківського університету висвітлювалися результати прикладних досліджень науковців, що здійснювалися в інтересах розвитку народного господарства й охорони здоров'я Харківщини й Донбасу. У грудні 1907 р. окремою збіркою були видані матеріали 3 нагоди святкування 30-річчя наукової, педагогічної й 
громадської діяльності професора I. Осипова (XXX-letie nauchnoi, pedagogicheskoi i obshchestvennoi deiatelnosti professora I. P. Osipova, 1910). Висвітлення ціннісних орієнтацій відомого ученого сприяло поширенню серед представників наукової спільноти образу науковця-гуманіста, популяризатора ідей раціоналізму, прогресу наукового й соціального.

Видання наукових товариств університету були відомими за межами Слобожанщини. До складу товариств залучалися представники інших міст країни (Києв, Рига, Новочеркаськ, Томськ та ін.) (Lutaieva, 2019), про діяльність яких повідомлялося на сторінках названих вище періодичних видань. Наукові часописи розвивали науковий світогляд здобувачів освіти. За таких обставин часописи наукових товариств сприяли об'єднанню фахівців та студентської молоді різних регіонів для передачі знань та інновацій, налагодженню комунікацій.

Задовольняючи інформаційну потребу освітян у знаннях педагогічної спрямованості, науковці Харківського університету залучалися до рецензування творів відомих на той час педагогів. Так, окремі рецензії публікувалися у періодичному виданні університету («Записки Харківського університету»). Така практика дозволяла популяризувати інформацію щодо методики виховання. У рецензії професора Івана Віссаріоновича Троїцького стосовно праці, виданої на честь Петра Францевича Лесгафта, визнавалася видатна роль науковця у справі організації фізичного виховання (Troitskii, 1912). Так само як і П. Лесгафт, І. Троїцький відстоював думку про те, що фізичне виховання має пов'язуватись із розумовим. Доцільно процитувати слова самого П. Лесгафта з приводу згаданої тези: «У дійсності виявляється, що складніше підготувати розумово освічену людину до справи, розвинути в неї навички до свідомої праці, ніж змушувати вивчати такі предмети як граматика, географія... Розумова освіта є розвитком абстрактного мислення та є важливою у виробленні образу або ідеалу людської особистості, а фізичне виховання складається 3 уміння діяти та виявляти свою волю» (переклад авт.) (Lesgaft, 1902).

Показово, що I. Троїцький високо оцінював ідею відомого педагога стосовно позитивного значення гри у фізичному розвитку дитини (Troitskii, 1912). Визнання сучасними дослідниками гейміфікації (застосування типових елементів гри) одним із глобальних інноваційних трендів у суспільногуманітарному розвитку, актуалізує значущість науково-педагогічної спадщини ученого у період сьогодення.

Слід зазначити, що протягом імперської доби, 3 нагоди ювілею Харківського університету у 1905-1906 pр., було опубліковано видання, присвячене діяльності медичного факультету університету під редакцією 
I. Скворцова й Д. Багалія. За редакцією І. Осипова та Д. Багалія побачило світ видання, присвячене сторіччю історії фізико-математичного факультету. Названі праці містили історико-довідкову інформацію щодо напрямів та змісту педагогічної діяльності науковців-медиків та природодослідників. Між іншим, характеристика громадсько-просвітницької діяльності науковців також знайшла відбиття на сторінках видань (Lutaieva, 2019).

Зауважимо, що підготовка до святкування 100-річчя заснування університету спонукала професора медичного факультету М. Попова підготувати й опублікувати матеріали стосовно життя, службової та літературної діяльності науковців-медиків Харківського університету. Вивчення публікацій дозволяє стверджувати, що М. Попов, висвітлюючи життєдіяльність представників професорсько-викладацької колегії Харківського університету, насамперед, акцентував увагу на високий рівень професійної підготовки й морально-етичних якостей своїх колег. При цьому розвиток цих якостей пояснювався приналежністю учених до осередку інтелектуальної праці, до академічної школи на базі університету. Зокрема, у некролозі відомого хірурга, професора А. Подрєза, М. Попов намагався окреслити чинники, що визначили успішну науково-педагогічну кар'єру науковця. Зазначалося, що А. Подрєз був «продуктом медичного факультету Харківського університету» (Lutaieva, 2019), що наклало свій відбиток на уподобання вченого.

Установлено, що М. Попов у своїх публікаціях звертав увагу на особливу соціокультурну місію науковців-медиків, на постійне намагання 3 їх боку оновлювати, нарощувати вертикальні і горизонтальні наукові зв'язки у зарубіжному й вітчизняному соціокультурному просторі. Між іншим, науковець указував на значення закордонних відряджень у формуванні наукового світогляду представників професорсько-викладацької корпорації, поширенні їх авторитету за кордоном. Результати наукових розвідок науковців-медиків та природодослідників Слобожанщини та їх сумісних досліджень із науковцями провідних освітніх центрів у межах міжнародного простору протягом досліджуваного періоду публікувалися на сторінках не лише вітчизняних, а й закордонних спеціалізованих фахових видань (Lutaieva \& Fesenko \& Alokhina, 2017).

Важливо зауважити, що звіти науковців Слобожанщини про результати закордонних відряджень друкувалися як окремими збірками, так i на сторінках періодичних часописів («Записки Імператорського Харківського університету», «Харківський медичний журнал» та ін.) (Lutaieva, 2019; Alokhina \& Lutaieva, 2014-2015). Тривалі творчі поїздки за кордон надавали можливість науковцям ознайомитися з системою викладання в європейських 
університетах, сприяли формуванню педагогічної майстерності та впровадженню передового зарубіжного педагогічного досвіду у заклади вищої освіти.

Аналіз спеціальної літератури та архівних джерел дозволяє свідчити, що науковці Слобожанщини в статусі представників громадських установ протягом досліджуваного періоду поповнювали інформаційний простір матеріалами просвітницького характеру. Зокрема, як члени органів земського самоврядування, вони висвітлювали в окремих інформаційних виданнях шляхи самовдосконалення земських лікарів, окреслювали науковообгрунтовані організаційні засади функціонування земських та ремісничих шкіл як закладів народної освіти. Так, професор М. Мельников-Розведенков як прозектор Харківської губернської земської лікарні виступив 10 вересня 1910 р. на конференції лікарів указаного медичного закладу 3 промовою на тему «Із спогадів про С. С. Корсакова, як університетського та громадського діяча» (Melnikov-Razvedenkov, 1910). Зміст промови надалі було опубліковано на шпальтах спеціалізованого періодичного видання та окремою збіркою. Слід відзначити, що промова науковця націлювала слухачів на творчу діяльність на рівні власної особистості. Автор промови звертав увагу на намагання С. Корсакова поширити серед здобувачів освіти ідеї Просвітництва, що дозволяло схарактеризувати його як просвітителя.

Протягом досліджуваного періоду окремі науковці Харківського університету здійснювали поповнення інформаційного простору засобом участі у підготовці літературно-довідкового видання Харківського губернського статистичного комітету («Харківська збірка»), що виходила у 1887-1898 роках. Серед них був представник фізико-математичного факультету Андрій Миколайович Краснов, який залучався видавцями до розробки питань, пов’язаних із вивченням населення Слобідської України, природи регіону (Krasikov, 1995, June 28-29; Lutaieva, 2019)

Наприкінці XIX - на початку XX ст. науковці Харківського університету активізували зусилля щодо поширення наукової інформації на сторінках спеціалізованих періодичних та продовжуваних видань. Ці часописи видавалися за їх участі в Харкові. Серед видань медичної спрямованості слід назвати: «Вісник медицини» (1896-1897 рр.), «Харківський медичний журнал» (видання Харківського медичного товариства, 1906-1917рр.), «Російський журнал шкірних та венеричних хвороб» (1901-1916 рр.), «Архів психіатрії, неврології та судової психопатії» (1883-1899 рр.), «Вісник бальнеології, кліматології і фізіотерапії» (19101911 рр.), «Вісник курортів і лікувальних установ» (1908-1916 рр.), 
«Лікарсько-гігієнічний довідник» (1912 р.) та ін. (Miroshnichenko, 2006, November 20-22).

Слід сказати, що часопис «Бюлетені Харківського товариства любителів природи» був друкованим органом Харківського товариства любителів природи. Природознавець Валерій Іванович Талієв здійснював редакційну роботу. Цінними й корисними для широких кіл громадськості визнано матеріали, що висвітлювалися на шпальтах часопису, де була надана інформація стосовно освітніх екскурсій, виховуючого впливу природи на особистість.

Виступи науковців Слобожанщини досліджуваного періоду на з'їздах фахівців різнобічного спрямування розкривали актуальні проблеми виховання, народної, професійної й вищої освіти. Зміст доповідей знаходив відбиток в окремих публікаціях; у спеціалізованих періодичних виданнях та збірках матеріалів з'їздів; на сторінках педагогічних часописів.

Протягом досліджуваного періоду представники наукової спільноти Слобожанщини інтенсифікували діяльність у вільних просвітницьких організаціях культурно-освітнього, громадсько-благодійницького типу, 3 ініціативи яких інформаційний простір поповнювався публікаціями просвітницького характеру. Наприклад, за пропозицією професора В. Данилевського (грудень 1906 р.) «Харківське товариство поширення серед народу грамотності» (ХТГ) розпочало видання «Народної енциклопедії наукових і прикладних знань», адресованої дорослому читачеві. Укладачами окремих томів енциклопедії та авторами нарисів для неї стали науковцімедики (М. Бокаріус, О. Браунштейн, В. Данилевський, К. Георгієвський, В. Фавр, С. Ігумнов); природодослідники (В. Арнольді, І. Осипов, А. Краснов, О. Нікольський) (Lutaieva, 2019). На нашу думку, користуючись сучасною термінологією, ХТГ слід оцінити як форму об'єднання кваліфікованих людей у Харкові для передачі знань та інновацій, засобом залучення до просвітницької діяльності зацікавлених осіб зі спільноти регіону. Видання ж енциклопедії можливо прирівняти до реалізації успішної колективної проектної діяльності в інформаційному просторі.

Слід звернути увагу на намагання окремих науковців Харківського університету пропагувати в інформаційному просторі матеріалістичний природничо-науковий підхід до розгляду психічних явищ. Такий підхід озвучував авторитетний фізіолог Василь Якович Данилевський, виступаючи 3 промовою на з'їзді Товариства російських лікарів («Душа i природа», 1889 р.), на з’їзді російських природознавців і лікарів («Почуття і життя», 1894 р.). При цьому науковець торкався проблем, що були пов'язані 3 вихованням особистості. Установлено, що з публічною лекцією «Почуття і 
життя» науковець виступив також у Харківській міській думі (1894р.). Згодом доповіді ученого було опубліковано (Lutaieva, 2019).

Науковці Харківського університету поповнювали інформаційний простір публікаціями, присвяченими безпосередньо проблемам виховання. Так, у часописі «Російська школа», що визнавався у Російській імперії загальнопедагогічним журналом для школи та сім’丷, були надруковані статті науковця-медика I. Скворцова. Учений намагався популярно пояснити читачам принципові речі. Він зауважував: метою виховання людей має бути підготовка до розумної самостійної праці (Skvortsov, 1903).

На сторінках регіональної періодичної преси (газети «Харківські губернські відомості», «Южний край», «Ранок») розміщувалися публікації просвітницького характеру науковців-медиків та природодослідників Харківського університету (В. Грубе, В. Крилов, А. Краснов, І. Осипов та ін.). Показово, що А. Краснов був редактором щоденної суспільно-політичної й літературної газети «Южний край» протягом періоду з 1910 по 1912 рр. В опублікованих ним «Листах до батьків» («Южний край», 1911 р.), він висвітлював кращі досягнення інших країн світу у справі організації цілісного естетичного, морального, трудового, розумового та фізичного виховання (Lutaieva, 2019).

Установлено, що інформація про роль учених у розвитку регіону повідомлялася мешканцям міста у рубриці газети «Місцева хроніка». При цьому акцентувалася увага на намаганні вчених служити спільноті, розкривалася роль їх наукової спадщини у справі досягнення соціального благополуччя. Так, до відома громадськості періодично доводилася інформація стосовно життєдіяльності I. Мечникова, який у 1888 р. переїхав до Парижа й розпочав роботу в Інституті Пастера (Vikhanski, 2016). Зі сторінок газети «Южний край» дізнаємося, що у 1903 р. І. Мечников як завідувач біологічної секції Інституту Пастера в Парижі був обраний почесним членом Товариства дослідників природи при Харківському університеті (Zasedenie Obshchestva ispytatelei prirody, 1903, December). Зі свого боку, члени Харківського товариства поширення в народі грамотності на загальних зборах у 1915 р. одностайно прийняли рішення про необхідність надіслання телеграми I. Мечникову з текстом поздоровлення на честь його 70-річчя й розмістили цей текст на шпальтах місцевої газети (Sobranie Obshchestva gramotnosti, 1915, January 9).

Зазначимо, що, продовжуючи традиції просвітителів минулого представників наукової спільноти Імператорського Харківського університету, - науковці Каразінського університету і сьогодні проходять стажування за кордоном, вивчають особливості організації освітнього процесу у закордонних закладах вищої освіти. Науково-педагогічні 
працівники університету залучаються до участі в університетському проекті «Новітні психолого-педагогічні технології навчання». У результаті проведеної роботи удосконалюється науково-методичне забезпечення освітнього процесу з урахуванням специфіки викладання дисциплін різного профілю; поповнюється банк новітніх психолого-педагогічних технологій, спрямованих на забезпечення якісної підготовки сучасних фахівців. Досягнення науковців як результат роботи над проектом висвітлюються у матеріалах щорічних конференцій (різного профілю), на сторінках періодичного видання «Наукові записки кафедри педагогіки», у монографіях (Zhukova, 2019; Lutaieva, 2019) та інших виданнях. Інформаційний простір освіти поповнюється також завдяки онлайнобміну в автономному режимі на базі Центру електронного навчання ХНУ імені В. Н. Каразіна, що здійснюється з метою забезпечення потреб освітян у ноосферизації освіти (формування нового мислення людини і критично-інноваційного потенціалу університету).

Сьогодні науковці ХНУ імені В.Н. Каразіна висвітлюють проблему соціального та психологічного благополуччя в історичному контексті в матеріалах конференцій (конференція, присвячена діяльності Ф. Нансена в Україні в 1921-1922 роках, 10-11 жовтня 2019 р. та ін.); організовують просвітницькі заходи з метою поширення наукових знань («Ніч науки», «Ніч історії Харкова» та ін.), повідомляючи про них у соціальних мережах Інтернету. 3 нагоди 215-ї річниці заснування медичного факультету Імператорського Харківського університету (започаткована перша академічна вища медична школа в Україні) на базі Каразінського університету відбувся Другий з'їзд Істориків Медицини України. Робота з'їзду (2-23 жовтня 2019 р., м. Харків) сприяла спрямуванню істориків медицини щодо подальшого аналізу історичного досвіду й поширення в інформаційному просторі матеріалів стосовно досягнень вітчизняної медичної науки.

Педагогічні й науково-педагогічні працівники, зокрема й медичної спрямованості, отримують нагоду відвідувати семінари, що проводяться на базі кафедри педагогіки ХНУ імені В.Н. Каразіна; обмінюватися матеріалами методичного характеру, залучаючись до заходів Центру електронного навчання університету; беруть участь у міжнародних науковопрактичних конференціях («Проблеми та шляхи реалізації компетентнісного підходу в сучасній освіті» та ін.) й мають можливість публікувати результати своїх досліджень в університетських виданнях. Без сумніву, життєдіяльність науковців Слобожанщини кінця XIX - початку XX ст. надихає сучасних представників наукового співтовариства класичного університету до 
розширення багатоманітних форм обміну інформацією, надаючи особистісну інтерпретацію світу культури, спрямовуючи культурний розвиток регіону, приймаючи до уваги наукові, духовні, освітні потреби громадськості.

Обговорення. Протягом досліджуваного періоду за участі науковців Слобожанщини інформаційний простір (зокрема, спеціалізований інформаційний простір, інформаційний простір освіти) збагачувався результатами їх інтелектуальної діяльності. Натомість сама ця діяльність втрачала сугубо елітарний характер й слугувала потребам просвітительства, сприяла формуванню більш широких знаннєвих полів, спрямовувала представників наукової спільноти до інтересів широких верств громадськості. Як у минулому, так і в період сьогодення поповнення представниками наукової спільноти інформаційного простору матеріалами просвітницького характеру є дієвим способом консолідації учених, освітян, студентів, пересічних громадян із метою забезпечення еволюціонування освіти, розвитку науки, поширення культурних надбань.

Проведене дослідження дозволяє стверджувати, що науковці Слобожанщини досліджуваного періоду, поповнюючи інформаційний простір матеріалами просвітницького характеру, уможливили діалог між різними поколіннями мешканців регіону, незалежно від того, чи є вони сучасниками. У період сьогодення науковцям корисно визначати власні ціннісні орієнтації, приймаючи до уваги різновекторну просвітницьку діяльність представників наукової спільноти.

Висновки. Вважаємо доцільним розглядати інформаційний простір як домінантну складову культури протягом конкретного історичного періоду, що сприяє обгрунтуванню певної картини дійсності окремої особистості. Важливими складовими інформаційного простору слід уважати спеціалізований інформаційний простір та інформаційний простір освіти.

До основних напрямів діяльності науковців Слобожанщини досліджуваного періоду у справі поповнення інформаційного простору матеріалами просвітницького характеру віднесено: діяльність просвітителів у інформаційному просторі Імператорського Харківського університету (публікації освітньо-наукового характеру у часописах університету; публікації доповідей, оголошених на зібраннях наукових товариств, що діяли при університеті; публікації ювілейних видань з історії університету та ін.); просвітницьку діяльність за межами університетського простору (популяризація в інформаційному просторі освіти даних про природу, населення, культуру регіону засобом публікацій у виданнях губернських і міських установ, на сторінках місцевої періодичної преси; публікації статей у закордонних та вітчизняних регіональних наукових виданнях; збагачення 
інформаційного простору освіти матеріалами стосовно ідеалів Просвітництва, актуальних проблем виховання, народної, професійної й вищої освіти тощо).

Установлено, що завдяки старанням науковців-медиків Данилевський, І. Скворцов, В. Грубе, В. Крилов, М. Бокаріус, О. Браунштейн, К. Георгієвський, В. Фавр, С. Ігумнов, М. Мельников-Розведенков, М. Попов, I. Троїцький та ін.) і природодослідників (А. Краснов, І. Осипов, В. Арнольді, O. Нікольський та ін.) збагачувалася інтелектуальна складова інформаційного простору, якісно перетворювався простір вільного часу пересічних громадян, розширювався діапазон інтересів i можливостей самореалізації у соціумі мешканців регіону, тривала консолідація суспільства та виявлялися ресурси його розвитку. Видавнича діяльність просвітницького характеру науковців Харківського університету на базі ХТГ (видання народної енциклопедіï) $\epsilon$ прикладом для сучасних учених, що створюють центри спільного інноваційного простору. Матеріали науковців Слобожанщини стосовно значущості ігрової діяльності, що поширювалися в інформаційному просторі освіти протягом досліджуваного періоду, можуть бути корисними у процесі гейміфікації освіти сьогодні.

\section{ЛІТЕРАТУРА:}

Alokhina N. V., Lutaieva T. V. Psychological and pedagogical conditions of multicultural competence of future specialists in medical and pharmaceutical industry. Europejskie studia humanistyczne : Państwo i Społeczeństwo. 2014-2015. № 2. P. 44-55.

Lutaieva T., Fesenko V., Alokhina N. Role of intercultural communications in implementation of innovations in higher education: historical and pedagogical aspects. European Humanities studies: State and society. 2017. № 1. P. 140 - 153.

Vikhanski L. Immunity: How Elie Metchnikoff Changed the Course of Modern Medicine. Chicago : Chicago Review Press, 2016. 336 p.

XXX-летие научной, педагогической и общественной деятельности профессора И. П. Осипова : [крат. биогр.. очерк и торжественное заседание Общества физикохимических наук 1 декабря 1907 г.]. Общество физико-химических наук при Харьковском университете. Х. : Печатное дело, 1910. 39 с.

Бак М. Поняття інформаційного простору освіти в структурі сучасного педагогічного дискурсу. Вісник Інституту розвитку дитини. Сер. : Філософія, педагогіка, психологія. 2014. Вип. 35. С. 5-12.

Жукова О. А. Дидактичні засади формування соціальної компетентності студентів класичних університетів засобами ігрових технологій : монографія. Х. : Мітра, 2019. $593 \mathrm{c}$.

Заседение Общества испытателей природы. Южный край. 1903. 23 декабря.

Кодекс цінностей Харківського національного університету імені В. H. Каразіна. URL : https://www.univer.kharkov.ua/ua/general/docs/kodeks (дата звернення : 05.06.2019).

Красіков М. М. Краєзнавча діяльність Харківського губернського статистичного комітету (1861-1917 рр.). Всеукраїнська краєзнавча конференція, присвячена 70-річчю укр. ком. краєзнавства : тези доп. конф., 28-29 червня 1995 р. Харків, 1995. С. 23-25.

Лесгафт П. К вопросу о физическом воспитании в школе. Научное обозрение: ежемесячный научно-философский и литературный журнал. 1902. № 5. С. 26-36. 
Лутаєва Т. В. Педагогічна та громадсько-просвітницька діяльність фундаторів вищої медичної та фармацевтичної освіти: регіональний історико-педагогічний аспект. Х. : Видавництво Іванченка I. С., 2019. 599 с.

Мельников-Разведенков Н. Ф. Из воспоминаний о С. С. Корсакове, как университетском и общественном деятеле : речь на конференции врачей Харьковской губернской земской больницы 10 сент. 1910 г. Харьков : Тип. и лит. М. Зильберберг и С-вья, 1910. 10 с. Отд. отт. из «Современной психиатрии», 1911 г.

Мірошніченко С. В. Харківський періодичний друк у XIX - на початку XX століття (на основі матеріалів Харківських наукових бібліотек). Збереження бібліотечноінформаційних ресурсів України: нова політика і нові технології : матеріали Всеукраїнської науково-практичної конференції (Харків, 20-22 листопада 2006 р.). Х., 2006. С. 79-90.

Садівничий В. «Відродження розпочинається із гласності...» : (Медична преса Наддніпрянської України середини XIX - початку XX ст.) : монографія. Дніпропетровськ : Середняк Т. К., 2015. 360 с.

Скворцов И. П. О воспитании нравственности. Русская школа. 1903. № 1. С. 80-94.

Словник української мови. В 11 т. За ред. І. К. Білодіда; АН УРСР. Інститут мовознавства. Київ : Наук. думка, 1975. URI: http://ukrlit.org/slovnyk/ slovnyk_ukrainskoi_movy_v_11_tomakh (дата звернення: 20.02 2016).

Собрание Общества грамотности. Южный край. 1915. 9 янв.

Талиев В. И. Рецензия на книгу «Русские учителя за границей». Бюллетени Харьковского общества любителей природы. 1913. № 2. С. 76-77.

Троицкий И. В. Отзыв на издание «Памяти Петра Францовича Лесгафта под. редакцией С.-Петербургской биологической лаборатории П.Ф. Лесгафта». Записки Императорского Харьковского университета. 1912. Кн. 1. Критика и библиография. С. 1-11.

Явление периодичности в развитии человеческого организма. Значение этого явления педагогическое, медицинское вообще и в этиологии инфекционных болезней в частности д-ра мед. И. Атласова (доложено на заседании Общества 31 окт. 1901г.). Труды Общества научной медицины и гигиены Императорского Харьковского Университета за 1900-1901 год. Х., 1904. С. 1-37.

Яковенко М. Інформаційний простір: філософські аспекти формування поняття. Вісник Національного університету «Львівська політехніка». Серія: Філософські науки. 2011. № 692. C. 22-27.

\section{REFERENCES:}

Alokhina, N. V. \& Lutaieva, T. V. (2014-2015). Psychological and pedagogical conditions of multicultural competence of future specialists in medical and pharmaceutical industry. Europejskie studia humanistyczne : Państwo i Społeczeństwo. 2, pp. 44-55.

Bak, M. (2014). Poniattia informatsiinoho prostoru osvity v strukturi suchasnoho pedahohichnoho dyskursu [The concept of educational information space in the structure of modern pedagogical discourse]. Visnyk Instytutu rozvytku dytyny. Ser. : Filosofiia, pedahohika, psykholohiia. 35. 5-12 (in Ukranian).

Bilodid, I. K. (Ed.). (1975). Slovnyk ukrainskoi movy [Dictionary of the Ukrainian language]. Kyiv : Nauk. dumka. Retrieved from: http://ukrlit.org/slovnyk/ slovnyk_ukrainskoi_movy_v_11_tomakh (in Ukranian).

Iakovenko, M. (2011). Informatsiinyi prostir: filosofski aspekty formuvannia poniattia [Information space: philosophical aspects of concept formation.]. Visnyk Natsionalnoho universytetu «Lvivska politekhnika». Ser.: Filosofski nauky. 692, pp. 22-27 (in Ukranian).

Iavlenie periodichnosti $v$ razvitii chelovecheskogo organizma. (1904). Znachenie etogo iavleniia pedagogicheskoe, meditsinskoe voobshche i v etiologii infektsionnykh boleznei v chastnosti d-ra med. I. Atlasova (dolozheno na zasedanii Obshchestva 31 okt. 1901g.) [The phenomenon of periodicity in the development of the human body. The significance of this phenomenon is 
pedagogical, medical in general and in the etiology of infectious diseases, in particular Doctor of Medicine I. Atlasov (reported at the meeting of the Company on October 31, 1901).]. Trudy Obshchestva nauchnoi meditsiny i gigieny Imperatorskogo Kharkovskogo Universiteta za 19001901 god. Kharkov, pp.1-37. (in Russian).

Kodeks tsinnostei Kharkivskoho natsionalnoho universytetu imeni V. N. Karazina (2019). [Valuation Code of V. N. Karazin Kharkiv National University]. Retrieved from : https://www.univer.kharkov.ua/ua/general/docs/kodeks (in Ukranian).

Krasikov, M. M. (1995, June 28-29). Kraieznavcha diialnist Kharkivskoho hubernskoho statystychnoho komitetu (1861-1917 rr.) [Local History Activities of Kharkiv Provincial Statistical Committee (1861-1917)]. Paper presented at All-Ukranian Local lore Conf. (3-25). Kharkiv (in Russian).

Lesgaft, P. (1902). K voprosu o fizicheskom vospitanii v shkole [On the issue of physical education in school]. Nauchnoe obozrenie: ezhemesiachnyi nauchno-filosofskii i literaturnyi zhurnal. 5, pp. 26-36 (in Russian).

Lutaieva, T. \& Fesenko, V. \& Alokhina, N. (2017). Role of intercultural communications in implementation of innovations in higher education: historical and pedagogical aspects. European Humanities studies: State and society. 1, pp. 140 - 153.

Lutaieva, T. V. (2019). Pedahohichna ta hromadsko-prosvitnytska diialnist fundatoriv vyshchoi medychnoi ta farmatsevtychnoi osvity: rehionalnyi istoryko-pedahohichnyi aspect [Pedagogical and public-educational activities of the sponsors of higher medical and pharmaceutical education: regional historical and pedagogical aspect]. Kharkiv : Vydavnytstvo Ivanchenka I. S. (in Ukranian).

Melnikov-Razvedenkov, N. F. (1910). Iz vospominanii o S. S. Korsakove, kak universitetskom i obshchestvennom deiatele : rech na konferentsii vrachei Kharkovskoi gubernskoi zemskoi bolnitsy 10 sent. 1910 g. [From the memories of S.S. Korsakov as a university and public figure: a speech at a conference of doctors of the Kharkov Provincial Zemsky Hospital on September 10, 1910]. Kharkov : Tip. i lit. M. Zilberberg i S-via (in Russian).

Miroshnichenko, S. V. (2006, November 20-22). Kharkivskyi periodychnyi druk u XIX - na pochatku XX stolittia (na osnovi materialiv Kharkivskykh naukovykh bibliotek) [Kharkov periodicals in the 19th - at the beginning of the 20th century (based on the materials of Kharkov scientific libraries)]. Paper presented at All-Ukranian Conference «Conservation of library and information resources of Ukraine: new policy and new technologies» (79-90). Kharkiv (in Ukranian).

Sadivnychyi, V. (2015). «Vidrodzhennia rozpochynaietsia iz hlasnosti...»: (Medychna presa Naddniprianskoi Ukrainy seredyny XIX - pochatku XX st.) [«Renaissance begins with publicity ...»: (Medical press of the Dnieper Ukraine in the mid-19th - early 20th centuries)]. Dnipropetrovsk : Seredniak T. K. (in Ukranian).

Skvortsov, I. P. (1903). O vospitanii nravstvennosti [On the upbringing of morality]. Russkaia shkola. 1, p. 80-94. (in Russian).

Sobranie Obshchestva gramotnosti (1915, January 9). [Meeting of the Literacy Society] Iuzhnyi krai (in Russian).

Taliev, V. I. (1913). Retsenziia na knigu «Russkie uchitelia za granitsei» [Review of the book «Russian Teachers Abroad»]. Biulleteni Kharkovskogo obshchestva liubitelei prirody. 2, pp. 76-77. (in Russian).

Troitskii, I. V. (1912). Otzyv na izdanie «Pamiati Petra Frantsovicha Lesgafta pod. redaktsiei S.Peterburgskoi biologicheskoi laboratorii P. F. Lesgafta» [Review of the edition «In Memory of Peter Frantsovich Lesgaft under. edited by P.F. Lesgaft, St. Petersburg Biological Laboratory»)]. Zapiski Imperatorskogo Kharkovskogo universiteta. In . 1. Kritika i bibliografiia, pp. 1-11 (in Russian).

Vikhanski, L. (2016). Immunity: How Elie Metchnikoff Changed the Course of Modern Medicine. Chicago : Chicago Review Press. 
XXX-letie nauchnoi, pedagogicheskoi i obshchestvennoi deiatelnosti professora I. P. Osipova : [krat. biogr. ocherk i torzhestvennoe zasedanie Obshchestva fiziko-khimicheskikh nauk 1 dekabria 1907 g.] (1910). [30th anniversary of the scientific, pedagogical and social activities of Professor I.P. Osipov: [brief biographical sketch and solemn meeting of the Society of Physical and Chemical Sciences at December 1, 1907]] Obshchestvo fiziko-khimicheskikh nauk pri Kharkovskom universitete. Kharkov : Pechatnoe delo (in Russian).

Zasedenie Obshhestva ispytatelej prirody. (1903). [Meeting of the Society of Nature Testers] Iuzhnyi krai (in Russian).

Zhukova, O. A. (2019). Dydaktychni zasady formuvannia sotsialnoi kompetentnosti studentiv klasychnykh universytetiv zasobamy ihrovykh tekhnolohii [Didactic principles of formation of social competence of students of classical universities by means of game technologies: monograph]. Kharkiv : Mitra. (in Ukranian).

\section{Інформація про автора:}

Лутасва Тетяна Василівна:

ORCID: https://orcid.org/0000-0002-5825560X, кандидат педагогічних наук, доцент, доцент кафедри педагогіки. Харківський національний університет імені В Н. Каразіна, майдан Свободи 4, Харків, Україна, 61022

e-mail: t.lutaeva@gmail.com

\section{Жукова Оксана Анатоліївна:}

ORCID: https://orcid.org/ 0000-0001-97249598, кандидат педагогічних наук, доцент, завідувач кафедри педагогіки, Харківський національний університет імені В. Н. Каразіна, майдан Свободи 4, Харків, Україна, 61022.

e-mail: edu.pedagogika@gmail.com

\section{Information about the author:}

\section{Lutaieva Tetiana Vasylivna:}

ORCID: https://orcid.org/0000-0002-5825560X, $\mathrm{PhD}$ in Pedagogy, Assoc. Prof. Pedagogy Department V. N. Karazin Kharkiv National University, 4 Svobody Sq., Kharkiv, Ukraine, 61022

e-mail: t.lutaeva@gmail.com

\section{Zhukova Oxana Anatoliivna:}

ORCID: https://orcid.org/ 0000-0001-97249598, PhD in Pedagogy, Assoc. Prof., heads of the Pedagogy Department, V. N. Karazin Kharkiv National University, 4 Svobody Sq., Kharkiv, Ukraine, 61022.

e-mail: edu.pedagogika@gmail.com

Цитуйте цю статтю як: Лутаєва Т.В., Жукова О.А. Роль науковців Слобожанщини у поповненні інформаційного простору матеріалами просвітницького характеру: регіональний історико-педагогічний підхід. Теорія та методика навчання та виховання. 2019. № 47. C. 63-78.

DOI: $10.34142 / 23128046.2019 .47 .06$

Дата надходження статті до редакції: 24.10.2019

Стаття прийнята до друку: 06.11.2019 